\title{
The Effect of Moringa oleifera to Hemoglobin Levels of Preconception Women in the Health Center Tibawa District Tibawa, Gorontalo
}

\author{
Yusna Mustapa ${ }^{1}$, Veny Hadju ${ }^{1 *}$, Rahayu Indriasari ${ }^{1}$, Healthy Hidayanti ${ }^{1}$, Saifuddin Sirajuddin ${ }^{1}$, Syamsiar S. Russeng $^{2}$ \\ ${ }^{1}$ Department of Nutrition, Faculty of Public Health, Hasanuddin University, Makassar, Indonesia; ${ }^{2}$ Department of Occupational \\ Health and Safety, Faculty of Public Health, Hasanuddin University, Makassar, Indonesia
}

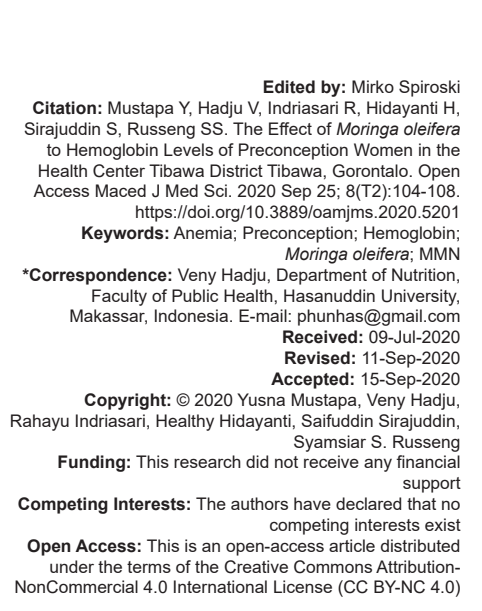

Abstract

BACKGROUND: The maternal mortality rate (MMR) in Gorontalo Province is still high at 194.7/100,000 live births Causes of high MMR include bleeding and anemia.

AIM: This study aimed to assess the effect of giving Moringa oleifera extract on the hemoglobin concentration of preconception women in the area of the health center Tibawa.

METHODS: This research method was a true experiment with a type of randomized controlled double-blind intervention of WUS aged 15-35 years with a sample of 44 people selected using purposive sampling techniques collected by trained personnel, including general data of respondents.

RESULTS: The results showed nutritional status and hemoglobin concentration in the treatment group of 12 people $(54 \%)$ with an increase in $\mathrm{Hb} 0.1-1.0 \mathrm{~g} / \mathrm{dl}$ and ten people $(45 \%)$ with an increase in $\mathrm{Hb} 1.5-2.0 \mathrm{~g} / \mathrm{dl}$ after the intervention, whereas in the control group of five people (22\%) with an increase in $\mathrm{Hb} 0.1-1.0 \mathrm{~g} / \mathrm{dl}$ and 17 people $(77 \%)$, there was no increase in $\mathrm{Hb}$ after the intervention. There was a significant difference in hemoglobin concentration in the treatment group with $p=0.000(p<0.05)$ with an average increase of 1.54 . There was a significant difference in hemoglobin concentration in controls with $p=0.025(p<0.05)$ with an average increase of 0.22 .

CONCLUSION: There is a difference in the effect between administration of $M$. oleifera extract that is more effective on hemoglobin concentration compared to MMN. It is hoped that in supporting government programs in reducing anemia in women of childbearing age, $M$. oleifera extract can be an alternative to giving blood-added tablets MMN.

\section{Introduction}

The World Health Organization targets a $50 \%$ reduction in the prevalence of anemia in WUS by 2025. Riskesdas 2013 data show the prevalence of anemia in WUS aged $>15$ years by $22.7 \%$, while for pregnant women by $37.1 \%$. Based on the results of Riskesdas in 2018, it showed that the proportion of anemia of pregnant women had increased to $48.9 \%$ from $37.1 \%$ and mostly occurred in pregnant women with group 15-24 years with a percentage of anemia in pregnant women in the Puskesmas area. This is an increase from 2017 , which is $8.3 \%$ [1].

Adolescent fertilization is an important issue in terms of health and social because it is related to the level of morbidity and mortality of mother and children. Mothers who are teenagers, especially $<18$ years, are more likely to experience problems in their babies or even experience childbirth related deaths compared to older women. SKDI 2012 results show that $10 \%$ of adolescents have become mothers, $7 \%$ had given birth, and $3 \%$ were pregnant with their first child [2].
The situation of public health status in Gorontalo Province in 2014 can be seen from the achievement of the maternal mortality rate (MMR) which still high at $194.7 / 100,000$ live birth. This number is declining compared to 2013, which reached 251.7/100,000 KLH. For the Tibawa health center area in 2018, the percentage of anemia in pregnant women was $10 \%$ (38 people), the number of pregnant women in the health center area. This was an increase from 2017 , which was $8.3 \%$.

The first 1000 days of life, which starts from the time of conception until the child is 2 years old, which is the most critical period to improve the child's physical and cognitive development. The nutritional status of women before conception can affect the critical development process during pregnancy and child born. In addition, women who intend to become pregnant are more vulnerable to suggestions for lifestyle changes [3].

Reproductive planning is very important in ensuring good outcomes for women and their offspring in the future. Sufficient micronutrient intake beforehand during the preconception period will provide additional benefits for malnourished girls and adult women as well as in cases of an unplanned pregnancy. Folic acid, 
vitamin $B$, and zinc have been shown to affect fetal development early in life, even before women realize that they are pregnant [4]. Preconception micronutrient interventions may be a promising approach to reducing iron deficiency during pregnancy [4], [5].

Research conducted by Young et al. [6] shows that the nutritional status of mother during preconception such as height and weight influences the nutritional status of children until 2 years of age. Mother $<150 \mathrm{~cm}$ in height and weight $<43 \mathrm{~kg} / \mathrm{m}^{2}$ increases the risk of stunting in children until 2 years (IRR incident risk ratio, respectively, $1.85,95 \% \mathrm{Cl} 1.51-2.28$ and IRR $1.35 .95 \% \mathrm{Cl} 110-1.65)$, BMI cut-offs $\left(<17 / \mathrm{m}^{2}\right.$ or $18.0 \mathrm{~kg} / \mathrm{m}^{2}$ ) 1.3 timer can increase the risk of stunting in children. Every $1 \mathrm{SD}$ increase the risk of stunting in an increase in maternal weight and height can increase 0.30 SD and 0.23 SD in the fetus until 2 years of age.

A study conducted by Amalia showed that there are still preconceptions women who are not compliant in taking MMN. Non-compliance with drug consumption is influenced by the explanation of the officers about the benefits of MMN [7].

According to research results, Moringa oleifera contains Vitamin A, Vitamin C, Vitamin B, calcium, potassium, iron, and protein, in very high amounts that are easily digested and assimilated by the human body. M. oleifera is the leaves of Moringa trees that contain a variety of macro and micronutrients as well as active ingredients that are as antioxidants. It contains essential nutrients such as iron (fe) $28.2 \mathrm{mg}$, calcium (ca) $2003.0 \mathrm{mg}$ and vitamin A $16.3 \mathrm{mg}$ rich in $\beta$-carotene, protein, Vitamins $A, C, D, E, K$, and $B$ (thiamine, riboflavin, niacin, pantothenic acid, biotin, Vitamin B6, Vitamin B12, and folate), various types of antioxidant compounds such as ascorbic acid, flavonoids, phenolics, and carotenoids. Moringa eggs are used as the main ingredient for hundreds of drugs, both for prevention and treatment [8].

Especially for the Gorontalo community, they only use this plant as a fodder and live fence. Lack of socialization about the benefits of Moringa has resulted in the low consumption of Moringa [9].

\section{Materials and Methods}

This research was conducted in the area of the Puskesmas Tibawa, Tibawa Subdistrict, Gorontalo Regency. This type of research is a true experimental study with a type of randomized controlled intervention double-blind design.

The population in this study were all preconception women registered in the area of the Puskesmas Tibawa regency aged 15-35 years, who were married and registered in the KUA of the Tibawa District, which were 703 people. There were 22 samples for the treatment group and 22 control groups that met the inclusion criteria, namely, preconception women registered in the KUA of the Tibawa subdistrict aged 15-35 years, who suffer from mild-moderate anemia with hemoglobin levels ( $<10 \mathrm{~g} / \mathrm{dl}-7 \mathrm{~g} / \mathrm{dl})$, willing to receive M. oleifera extract capsules, and MMN for 6 weeks, do not consume multivitamins and other minerals during the study and are willing to sign informed consent.

Data collection was carried out by interview using a structured questionnaire to get data on maternal characteristics, namely, data on age, education, income, and pregnancy history, measurement of hemoglobin. Data collection for hemoglobin was carried out twice, namely, before the intervention and after conducted and intervention.

Univariate analysis is used to obtain a description of the frequency distribution of respondent characteristics, including data on age, education, income, and history of pregnancy. Bivariate analysis was used to assess differences in mean before and after treatment in each group with paired t-test, if the data distribution was normal, and the Wilcoxon test if the data distribution was not normal. To see the difference in mean changes between the two groups, the independent t-test was used if the data distribution was normal and the Mann-Whitney U-test if the data were not normal.

\section{Results}

Table 1 shows that the majority of respondents in the two groups were vulnerable aged 20-35 years, had the number of children 1 person, occupation as a household RT, and the level education last junior high, the results of statistical tests of differences in the two groups at the beginning of the study showed that both groups were significantly different $(p>0.05)$, which indicate that the two groups have equality for the variable characteristics of aged, number of children, work and education, and income.

Table 1: Characteristics of respondent

\begin{tabular}{|c|c|c|c|c|c|}
\hline \multirow[t]{2}{*}{ Variables } & \multicolumn{2}{|c|}{ Intervention group } & \multicolumn{2}{|c|}{ Control group } & \multirow[t]{2}{*}{$P$} \\
\hline & $\mathrm{n}$ & $\%$ & $n$ & $\%$ & \\
\hline \multicolumn{6}{|l|}{ Age } \\
\hline$<20$ year & 6 & 37.5 & 10 & 62.5 & \multirow[t]{3}{*}{0.174} \\
\hline $20-35$ year & 16 & 57.1 & 12 & 42.9 & \\
\hline$>35$ year & 0 & 0 & 0 & 0 & \\
\hline \multicolumn{6}{|l|}{ Parity } \\
\hline 0 & 6 & 27.3 & 5 & 22.7 & \multirow[t]{3}{*}{0.627} \\
\hline 1 & 14 & 63.6 & 13 & 59.1 & \\
\hline 2 & 2 & 9.09 & 4 & 18.2 & \\
\hline \multicolumn{6}{|l|}{ Work } \\
\hline IRT & 21 & 95.5 & 22 & 100 & \multirow[b]{2}{*}{0.500} \\
\hline Private & 1 & 4.5 & 0 & 0 & \\
\hline \multicolumn{6}{|l|}{ Education } \\
\hline SD & 2 & 9.1 & 8 & 36.4 & \multirow[t]{4}{*}{0.19} \\
\hline SMP & 10 & 45.5 & 11 & 50.0 & \\
\hline SMA & 10 & 45.5 & 2 & 9.09 & \\
\hline PT & 0 & 0 & 1 & 4.5 & \\
\hline \multicolumn{6}{|l|}{ Income } \\
\hline$<2,500,000$ & 21 & 95.5 & 21 & 95.5 & \multirow[t]{2}{*}{0.579} \\
\hline$>2,500,000$ & 1 & 4.5 & 1 & 4.5 & \\
\hline
\end{tabular}

Table 2 shows that in the capsule group intervention before intervention, as many as 18 people 
(81.8) had mild anemia, and four people (18.1\%) had moderate anemia. Then, after the intervention for 6 weeks, 3 people (13.6\%) had normal $\mathrm{Hb}$ status, 18 people $(81.8 \%)$ were mild, and one person $(4.5 \%)$ had moderate $\mathrm{Hb}$ status.

Table 2: Distribution subject according to hemoglobin levels before and after intervention to group intervention to woman preconception in area health center Tibawa 2019

\begin{tabular}{|c|c|c|c|c|c|}
\hline \multirow{2}{*}{$\begin{array}{l}\text { Clasifika status } \\
\text { hemoglobin }\end{array}$} & \multirow[t]{2}{*}{ Hemoglobin levels } & \multicolumn{2}{|c|}{ Before intervention } & \multicolumn{2}{|c|}{ After intervention } \\
\hline & & $\mathrm{n}$ & $\%$ & $n$ & $\%$ \\
\hline Normal & $>12 \mathrm{~g} / \mathrm{dl}$ & 0 & 0 & 3 & 13.6 \\
\hline Mild anemia & $9-11.9 \mathrm{~g} / \mathrm{dl}$ & 18 & 81.8 & 18 & 81.8 \\
\hline Moderate anemia & $7.0-8.9 \mathrm{~g} / \mathrm{dl}$ & 4 & 18.1 & 1 & 4.5 \\
\hline Severe anemia & $<7 \mathrm{~g} / \mathrm{dl}$ & 0 & 0 & 0 & 0 \\
\hline Number & & 22 & 100 & 22 & 100 \\
\hline
\end{tabular}

Table 3 shows that in the group control before intervention, as many as 21 people $(95.5 \%)$ had mild anemia, and one person (4.5\%) had moderate anemia. However, after 6 weeks of intervention, the status of hemoglobin in the group control subjects remained constant, with 21 people $(95.5 \%)$ having mild anemia and one people $(4.5 \%)$ having moderate anemia.

Table 3: Distribution subject according to hemoglobin levels before and after the intervention to group control to woman preconception in area health center Tibawa 2019

\begin{tabular}{|c|c|c|c|c|c|}
\hline \multirow{2}{*}{$\begin{array}{l}\text { Clasifikasi status } \\
\text { hemoglobin }\end{array}$} & \multirow[t]{2}{*}{ Hemoglobin levels } & \multicolumn{2}{|c|}{ Before intervention } & \multicolumn{2}{|c|}{ After intervention } \\
\hline & & $n$ & $\%$ & $\mathrm{n}$ & $\%$ \\
\hline Normal & $>12 \mathrm{~g} / \mathrm{dl}$ & 0 & 0 & 0 & 0 \\
\hline Mild anemia & $9-11.9 \mathrm{~g} / \mathrm{dl}$ & 21 & 95.5 & 21 & 95.5 \\
\hline Anemia moderate & $7.0-8.9 \mathrm{~g} / \mathrm{dl}$ & 1 & 4.5 & 1 & 4.5 \\
\hline Severe anemia & $<7 \mathrm{~g} / \mathrm{dl}$ & 0 & 0 & 0 & 0 \\
\hline
\end{tabular}

Table 4 shows that the change in hemoglobin $\mathrm{Hb}$ concentration in the group intervention was 12 people $(54 \%)$ with an increase in $\mathrm{Hb} 0.1-1.0 \mathrm{~g} / \mathrm{dl}$ and ten people (45\%) with an increase in $\mathrm{Hb}$ with an increased in $\mathrm{Hb} 1.5-2.0 \mathrm{~g} / \mathrm{dl}$ after the intervention, whereas in group control of 5 people $(22 \%)$ with an increase in $\mathrm{Hb} 0.1-1.0 \mathrm{~g} / \mathrm{dl}$ and 17 people $(77 \%)$, there was no increase in $\mathrm{Hb}$ after the intervention.

Table 4: Distribution subject according to hemoglobin levels before and after intervention to group intervention and group control to woman preconception in area health center Tibawa 2019

\begin{tabular}{llllll}
\hline Change of hemoglobin $(\mathrm{g} / \mathrm{l})$ & \multicolumn{2}{c}{ Before intervention } & & \multicolumn{2}{c}{ After intervention } \\
\cline { 2 - 3 } & $\mathrm{n}$ & 0 & & $\mathrm{n}$ & $\%$ \\
\hline$<0.1$ & 12 & 0 & & 17 & 77 \\
$0.1-1.0$ & 0 & 54 & & 5 & 22 \\
$1.0-1.5$ & 10 & 0 & & 0 & 0 \\
$1.5-2.0$ & 22 & 45 & & 0 & 0 \\
Total & & 100 & & 22 & 100 \\
\hline
\end{tabular}

Table 5 shows that the change in hemoglobin $\mathrm{Hb}$ concentration group intervention was 12 people $(54 \%)$ with an increase in $\mathrm{Hb} 0.1-1.0 \mathrm{~g} / \mathrm{dl}$ and ten people $(45 \%)$ with an increase in $\mathrm{Hb} 1.5-2.0 \mathrm{~g} / \mathrm{dl}$ after the intervention, whereas in group control of 5 people $(22 \%)$ with an increase in $\mathrm{Hb} 0.1-1.0 \mathrm{~g} / \mathrm{dl}$ and 17 people $(77 \%)$, there was no increase in $\mathrm{Hb}$ after intervention.

Table 5: Analysis subject according to hemoglobin levels before and after intervention to group intervention and group control to woman preconception in area health center Tibawa 2019

\begin{tabular}{|c|c|c|c|c|c|}
\hline \multirow[t]{3}{*}{ Group } & \multirow[t]{3}{*}{$\mathrm{n}$} & \multicolumn{2}{|c|}{ Hemoglobin (g/dl) } & \multirow[t]{3}{*}{$\Delta$ Mean } & \multirow[t]{3}{*}{$\mathrm{p}^{*}$} \\
\hline & & Pre-test & Post-test & & \\
\hline & & Mean \pm SD & Mean \pm SD & & \\
\hline Group intervention & 22 & $9.05 \pm 1.046$ & $10.59 \pm 1.054$ & 1.54 & 0.000 \\
\hline Group control & 22 & $9.55 \pm 0.912$ & $9.77 \pm 0.973$ & 0.22 & 0.025 \\
\hline$p^{* *}$ & & 0.043 & 0.005 & & \\
\hline
\end{tabular}

\section{Discussion}

A mother age is related to women reproductive organs. In this study, the majority $(63.6 \%)$ of respondents were vulnerable aged 20-35 years, and the rest $(36 \%)$ aged $<20$ years. This study is in accordance with research conducted by Aminingsih and Putra [10] that most of the age group of respondents $(50.1 \%)$ are vulnerable aged 20-35 years. It is considered that the majority of respondents already have a safe reproductive system for pregnancy preparation and also have a connection with the mental readiness of the mother to be able to accept the process of pregnancy.

Education is developing all abilities and human behavior through knowledge. In this study, the majority of respondents $(47.7 \%)$ had a junior high school level, and only $(2.7 \%)$ had the highest level of education, namely, S1. This greatly affects the level of acceptance of respondents aim absorbing knowledge related to health, especially anemia. The higher the mother's nutritional knowledge was, the higher the awareness to participate in the provision of food so that anemia is fulfilled, the $\mathrm{Hb}$ levels will increase where there is a tendency for each additional $1 \%$ of knowledge, the $\mathrm{Hb}$ levels will increase by $0.006 \mathrm{~g} / \mathrm{dl}$ [11].

Income is the real amount of income of all household members who are donated to meet the needs of both people and individuals in the household. In this study, most of the respondents 42 people (95.5\%) have income levels $<2,500,000 /$ month and only 2 people (5\%) have income $>2,500,000 /$ month. The low level of income in the household will affect the purchasing power of foodstuffs that contain nutrients.

Parity is the number of children born to a mother whether born or stillborn. This study showed that the majority of respondents, 27 people $(61.4 \%)$ had one child, and 11 people (25\%) did not have children. However, this respondent had planned for her pregnancy several years in advance. Parity is one of the factors that are assumed to have a relationship with the incidence of anemia in pregnant women. According to the recommendations issued by the BBKBN, the ideal pregnancy distance is 2 years or more because a short birth interval will cause that a mother is not enough to restore the condition of her body after giving birth before. Short pregnancy intervals tend to deplete maternal nutrition from pregnancy and blood loss during childbirth [2].

Maternal nutrition and health status during prepregnancy are very important, while breastfeeding is a very critical period for the growth and development of children. In this study, as many as six people (13.6\%) experienced KEK, and this was related to the risks that would be faced by expectant mothers and babies who would later be born. In this study, six people (13.6\%) respondents experienced KEK. The occurrence of 
KEK is influenced by several factors, both directly and indirectly. Family economic factors greatly affect the availability of food containing fe in the household. This can be seen from the total family income in the two treatment groups having an average income of $<\mathrm{Rp}$. $2,500,000$ by 42 people $(95.4 \%)$ and only two people $(4.5 \%)$ who have an income of $>$ Rp. $2,500,000$. This lack of income indirectly affects food intake, especially for expectant mothers. The amount of income spent on food can be used as a guideline for the level of household well-being and affect the power of Brli and the choice of food to be consumed [12], [13], [14].

M. oleifera is one type of tropical plant that is easy to grow in Indonesia. The high iron content of $M$. oleifera leaves is thought to be efficacious to overcome iron deficiency anemia by increasing the number of red blood cells so that it can increase blood viscosity and peripheral resistance of blood vessels that affect blood pressure. This study showed that there were significant differences in hemoglobin concentration in the group intervention with $\mathrm{p}=$ 0.000 ( $p<0.05)$. The results of $\mathrm{Hb}$ concentration measurements showed that there was an increase in $\mathrm{Hb}$ concentration in the group intervention which was $9.05 \pm 1.046$ (Mean \pm SD) at the initial measurement to $10.59 \pm 1.054$ at the end of the measurement, with an average increase of 1.54 . Hence, it can be assumed that Moringa leaf extract is very influential in increasing the concentration of preconception female hemoglobin.

One effort that has been made by the government is to support the 1000 HPK Movement, especially in overcoming anemia in WUS through the administration of MMN in the form of iron $(60 \mathrm{mg}$ $\left.\mathrm{FeSO}_{4}\right)$ and folic acid $(0.25 \mathrm{mg})$. This research shows that there is a significant difference in hemoglobin concentration in group control which had increased from $9.55 \pm 0.912$ (Mean \pm SD) to $9.77 \pm 0.973$ (Mean $\pm \mathrm{SD})$ at the end of the measurement with an average increase of 0.22 . Average $\mathrm{Hb}$ levels both before and after were significantly different $(p<0.05)$. Hence, it can be assumed that the intervention of MMN influences the increase in the concentration of preconception female hemoglobin, although the effect on hemoglobin is very different from the group intervention. Hence, that group intervention can be used as an alternative in increasing hemoglobin in preconception women.

\section{Conclusion}

There was a significant difference in hemoglobin concentration in the group given Moringa capsules by $p=0.000(p<0.05)$. M. oleifera extract has a more significant effect on the subject's hemoglobin concentration compared to MMN so that M. oleifera extract can be used as an alternative other than MMN. As for suggestions from this research in supporting government programs in reducing anemia in women of childbearing age, Moringa leaf extract can be an alternative to giving MMN.

\section{References}

1. Kementerian Kesehatan Republik Indonesia. Riset Kesehatan Dasar Tahun 2018. Jakata: Kementerian Kesehatan Republik Indonesia; 2018. https://doi.org/10.36407/akurasi.v2i2.177

2. Kementerian Kesehatan Republik Indonesia. Survey Demograf Dan Kesehatan Indonesia 2012. Jakarta: Kementerian Kesehatan Republik Indonesia; 2012.

3. Van Elten TM, Karsten MD, Geelen A, Van Oers AM, Van Poppel MN, Groen H, et al. Effects of a preconception lifestyle intervention in obese infertile women on diet and physical activity; a secondary analysis of a randomized controlled trial. PLoS One. 2018;13(11):20-4. https://doi.org/10.1371/journal.pone.0206888 PMid:30403756

4. Nguyen PH, Young M, Casanova IG, Pham HQ, Hieu N Truong VT, et al. Impact of preconception micronutrient supplementation on anemia and iron status during pregnancy and postpartum: A randomized controlled trial in rural Vietnam. PLoS One. 2016;11(12):e0167416. https://doi.org/10.1371/ journal.pone.0167416

PMid:27918586

5. Lassi ZS, Imam AM, Dean SV, Bhutta ZA. Preconception care: Caffeine, smoking, alcohol, drugs and other environmental chemical/radiation exposure. Reprod Health. 2014;11(3):S6. https://doi.org/10.1186/1742-4755-11-s3-s6

PMid:25415846

6. Young MF, Nguyen PH, Casanova IG,Addo OY, Tran LM, Nguyen S, et al. Role of maternal preconception nutrition on offspring growth and risk of stunting across the first 1000 days in Vietnam: A prospective cohort study. PLoS One. 2018;13(8):e0203201. https://doi.org/10.1371/journal.pone.0203201

PMid:30161206

7. Paridah P, Citrakesumasari C, Thaha AR. Peran kader posyandu pada pelayanan terpadu wanita prakonsepsi di wilayah Puskesmas Pattingalloang. Med Kesehatan Masyarakat Indones Univ Hasanuddin. 2014;10(2):102-9. https://doi. org/10.31934/mppki.v2i2.571

8. Yulianti H, Hadju V, Alasiry E. Pengaruh ekstrak daun kelor terhadap peningkatan kadar hemoglobin pada remaja putri di SMU Muhammadiyah Kupang. Health JST. 2016;6:399-404.

9. Rizkayanti R, Diah AW, Jura MR. Uji aktivitas antioksidan ekstrak Air dan Ekstrak Etanol Daun Kelor (Moringa Oleifera LAM). J Akademika Kimia. 2017;6(2):125-31. https://doi.org/10.22487/ j24775185.2017.v6.i2.9244

10. Aminingsih S, Putra AC. Hubungan tingkat pengetahuan tentang anemia dengan tindakan pencegahan anemia untuk persiapan kehamilan pada pasangan usia subur. J Kosala. 2019;7(1):1-11. https://doi.org/10.37831/jik.v7i1.164

11. Lestrina D, Nurhayati I, Martony O. Pengaruh promosi kesehatan terhadap peningkatan pengetahuan dan kadar hemoglobin pada WUS didesa Paluh Kemiri Kec. Lubuk Pakam. Wahana Inovasi. 2015;4(1):80-91.

12. Mallongi A, Stang AR, Syamsuar S, Natsir MF, Astuti RD, Rauf $A U$, et al. Potential ecological risks of mercury contamination along communities area in Tonasa cement 
industry Pangkep, Indonesia. Enfer Clín. 2020;30(4):119-22. https://doi.org/10.1016/j.enfcli.2019.10.054

13. Mallongi A, Limbong E, Naiem F, Ishak $\mathrm{H}$, Basri S, Syam A, et al. Health risk analysis of exposure to mercury $(\mathrm{Hg})$ and cyanide (CN) in Kayeli village communities Teluk Kayeli district Buru regency. Enfer Clín. 2020;30(4):427-30 https://doi.org/10.1016/j. enfcli.2020.03.007

14. Kusumawati SI, Indarto D, Hanim D, Suminah S. Hubungan asupan makanan, suplementasi Fe dan Assam folat dengan Kadar hemoglobin pada ibu hamil riwayat KEK dan anemia Saat Menyusui. Penelitian Gizi Dan Makanan. 2016;39(2):10310. https://doi.org/10.22435/pgm.v39i2.5155.103-110 